\title{
CHARACTERISTICS OF POPULATION INDICATORS OF BROWN HARE (LEPUS EUROPAEUS PALL.) OBTAINED DURING GROUP HUNTING IN THE REGION WITH THE HIGHEST DENSITY IN WESTERN PART OF THE LUBLIN REGION IN POLAND
}

\author{
FLIS, M. ${ }^{1}-$ RATAJ, B. ${ }^{2 *}$ \\ ${ }^{1}$ Department of Ethology of Animals and Hunting, Faculty of Animal Sciences and Bioeconomy, \\ University of Life Sciences in Lublin, 20-950 Lublin, Poland \\ (ORCID 0000-0001-7429-3158) \\ ${ }^{2}$ Polish Hunting Association, District Board Nowy Sacz, 33-300 Nowy Sacz, Poland \\ *Corresponding author \\ e-mail: brataj66@gmail.com
}

(Received 23 ${ }^{\text {rd }}$ Apr 2019; accepted 11 $1^{\text {th }}$ Jul 2019)

\begin{abstract}
The research was conducted in the hunting season 2017/18, during three group hunts. In total, 129 shot hares were covered. During the tests, body weight, age, and sex were determined. The achieved results indicate that the size of hunting harvest at the level of about 3 individuals/100 ha should be accepted as the highest in Poland, which is also a confirmation of the highest density of this species. They are also a confirmation of high individual condition expressed by body weight of both young $(4.10 \mathrm{~kg}$ ) and adults $(4.65 \mathrm{~kg})$. The structure of sex and age, as well as calculated reproduction rates (1.63) and reproductive success (2.42) indicate that the assessed population has developing features. The conducted research on the parameters characterizing the hare population in the area covered by the studies indicate high individual condition as well as reproductive potential, which allows to deduce about the potentially high potential for reconstruction of the number of hares.
\end{abstract}

Keywords: brown hare, body mass, age structure, sex structure, Lublin Upland

\section{Introduction}

In the last decades, a decreasing trend of the hare population has been observed in most European countries. Also in our country, the number and local density ratios, in many regions, have remained at a low and very low level for many years (Pielowski, 1976; Burel and Baudry, 1990; Dziedzic et al., 2002; Flis, 2009, 2016; Jezierski, 2004; Nasiadka and Dziedzic, 2014).

Although it is quite difficult to identify the unambiguous cause of this unfavorable trend, the most frequent changes are the changes in agrocenoses that are the main habitat for this species. Intensification of agriculture affecting quite significantly the heterogeneity of hare living environments, combined with the increase in the mechanization of all agrotechnical operations and the frequent use of plant protection products contributes to a significant simplification of agrocenosis structures (Lewandowski and Nowakowski, 1993; Panek and Kamieniarz, 1999; Dziedzic et al., 2000; Schmidt et al., 2004; Kryński et al., 2007; Kamieniarz et al., 2013; Schai-Braun et al., 2015; Panek, 2018). Another not less important factor influencing the hare population dynamics is predation, mainly free-living foxes (Pielowski, 1979; Goszczyński and Wasilewski, 1992; Panek et al., 2006; Panek, 2007; Wasilewski, 2007). The number of these predators in recent years has increased quite dramatically, 
which in turn was caused by the elimination of the basic mortality factor which was rabies. It is conditioned by the fact of conducting nationwide action of immunization of free-living foxes against rabies, starting from 2002 (Flis et al., 2017, 2018). Nevertheless, nowadays, in the conditions of low densities of hares populations occurring in many regions of the country, predation of foxes in hares in agrocenoses plays less and less influence on the dynamics of their numbers. The composition of the fox diet is more and more often sources of anthropogenic origin and small mammals (Gołdyn et al., 2003; Hušek et al., 2015; Panek, 2018). In addition, the negative impact of synanthropic predation on the population and thus the functioning of the population is also not without significance (Flis, 2013; Nasiadka and Dziedzic, 2014).

Quite significant factors affecting the dynamics of hares are also numerous disease entities. Coccidiosis and parasitic diseases are most often mentioned. However, bacterial and viral diseases such as brucellosis and hemorrhagic hare disease - EBHS and many other slightly less common (Pikula et al., 2004; Dubinský et al., 2010; Decors et al., 2011; Chroust et al., 2012; Kornaś et al., 2014; Nasiadka and Dziedzic, 2014; Flis et al., 2016). All described elements have a negative effect, and at the same time have a comprehensive impact on the functioning of the population of this species and they have led to a drastic reduction in densities. In the $70 \mathrm{~s}$ of the last century, the average population density in our country remained at the level of about 50 individuals per 100 areas of field hunting grounds (Pielowski, 1976, 1979). At the beginning of the 21st century, the average level of hares density in the country was varied in individual regions and was in the range of 5-9 individuals/100 ha (Dziedzic et al., 2002; Wasilewski, 2007; Flis, 2009, 2016).

The most frequently used measure of the individual quality and health status as well as the survival rates of wild animals is the individual condition resulting directly from the body weight. This indicator, combined with climatic factors and intra-population parameters such as sex structure and age structure, determines the reproductive potential of the population. As a rule, individuals in a lower individual condition are more susceptible to natural selection factors (Frylestam, 1980; Hackländer, 2011; Flis, 2015).

The aim of the study was to assess the individual condition expressed by the body weight of males and females of young and adult hares in conditions of hunting areas with high acquisition of this species. The assessment also included sex structure and age indicators that directly affect the reproductive potential of this species.

\section{Material and methods}

\section{Characteristics of the research area}

The research was conducted in two hunting districts with a total area of 13.600 ha, the forest cover of which is $25.2 \%$. They are located in the western part of the Lublin region, in the mesoregion of Kotlina Chodelska and the northern part of Wzniesienia Urzędowskie, in Poland, near the town of Opole Lubelskie (according to the WGS 84 reference system, the geographical coordinates are; width: $51^{\circ} 08^{\prime} 51^{\prime \prime} \mathrm{N}$, length: $21^{\circ} 58^{\prime} 08^{\prime \prime} \mathrm{E}$ ) (Fig. 1). This region is characterized by the presence of fertile soils of the chernozem type on the loess ground (Kondracki, 2000). Despite fairly fertile soils, it is distinguished by significant fragmentation of agricultural crops, and thus large heterogeneity of field environments. Field crops are dominated by plants with high soil requirements, with particular reference to orchards and plantations of perennial soft fruits, mainly raspberries and currants. In the agricultural landscape, there are numerous 
wastelands as well as small wooded enclaves and forest complexes (Witek, 1991). Heterogeneity evaluation of the natural environment of agrocenoses in the area of research, performed according to the method proposed by Schrödel (1991) showed an average size of individual fields at the level of 0.95 ha, while the average distance between landscape elements ranged from 0.5 to $0.7 \mathrm{~km}$. In turn, the relative length of contour lines in agrocenoses having significant impact on the functioning of small game population, despite the variation in individual regions of the study area, was on average at $0.1-0.2 \mathrm{~km} / \mathrm{km}^{2}$. All described elements determine quite significant mosaicism of field environments, creating almost optimal conditions for living and functioning of the hare population (Pielowski, 1979).

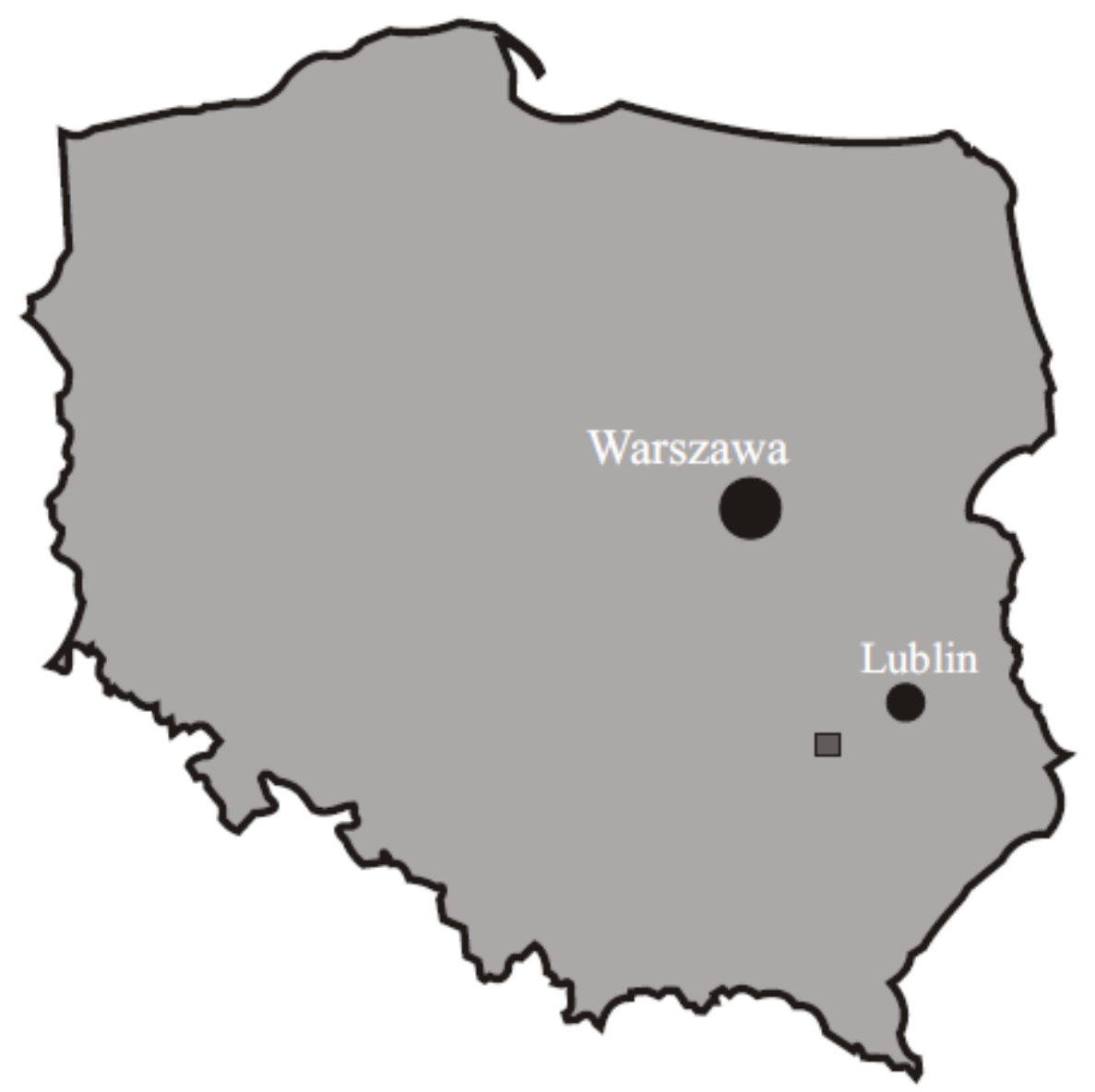

$\square$ - hunting districts constituting the research area

Figure 1. Location of the research area

\section{Material for research}

The research material were hares fired during collective hunts in November and December 2017. The hares were shot in the area with the highest density in the Lublin region. The annual number of assessments carried out by hunters indicate that the region has an average annual population size over the last 5 years, estimated at 1,100 individuals. With reference to the field surface of the area where the research was carried out, there is a density of 10 individuals per $1 \mathrm{~km}^{2}$. In total, the analyzes were 
carried out on 129 hares, of which 51 were male and another 78 females. Among the shots were 80 young hares and 49 adults. Additionally, in order to determine the level of compaction, a hunting analysis of this species was made during the last five hunting seasons.

\section{Methods and measurements}

All hares were weighed directly after the shot. Weighing was carried out with an accuracy of $0.1 \mathrm{~kg}$. Gender assessments were made based on the appearance of secondary sexual characteristics. The hog age was also determined directly in the field on the basis of the palpation assessment of the occurrence or disappearance of the Stroh mark (cartilaginous elbow base cap). Such an assessment allows the division of hares into young (up to 1 year old) and adult (over 1 year old) (Stroh, 1931; Pielowski, 1979) (Fig. 2).
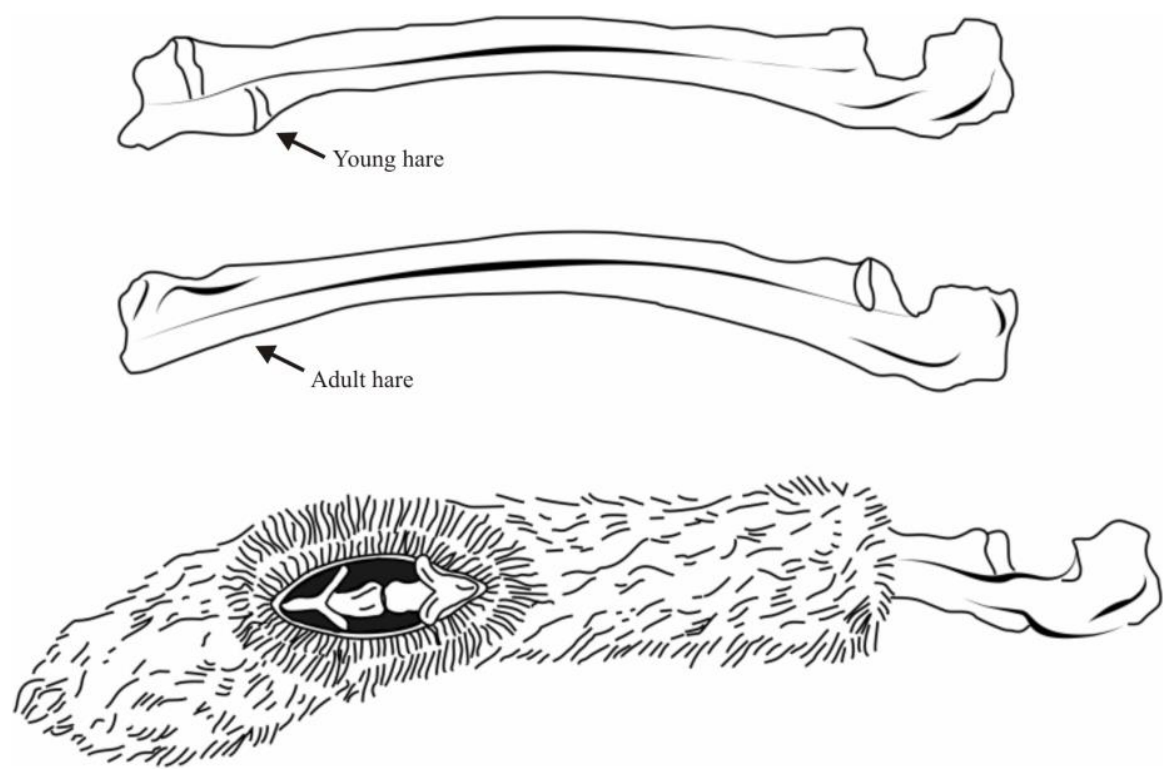

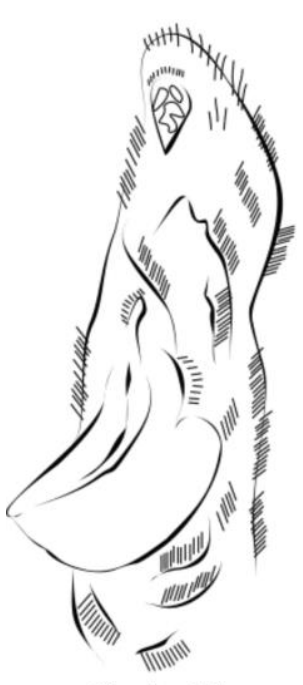

Female adult

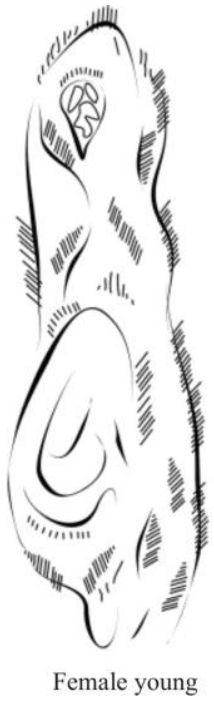

a

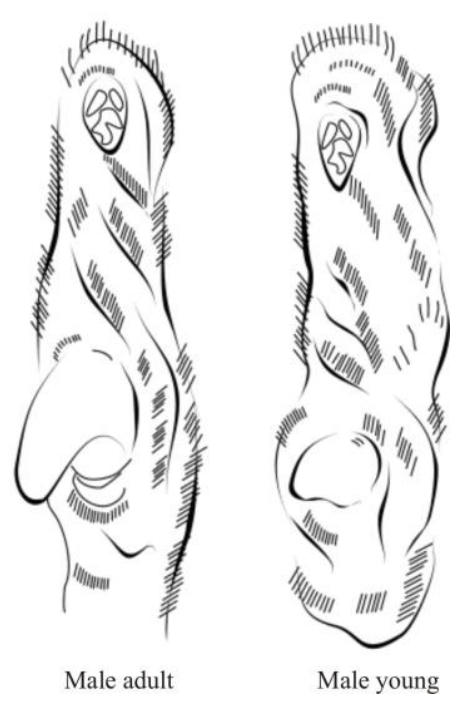

b

Figure 2. Recognition of the age of shot hares based on the Stroh sign (a) and gender based on the appearance of the external reproductive organs $(b)$ 


\section{Analysis}

The whole material was divided into age-gender groups, which allowed to determine the sex structure index and the age of the animals obtained. In order to determine the differences between average body weight values depending on the sex in separate age groups, hares were made a one-way analysis of variance. In order to verify the possible occurrence of differences between the averages, calculations were made using the Tukey test, in the Statistica program. The reproductive index and reproductive success rate were used to describe the dynamics of the population size (Pintur et al., 2006).

The reproduction rate was calculated as the ratio of the number of young hares that survived to the hunting season per 1 adult animal:

$$
W r=\frac{N j u v}{N a d}
$$

The reproductive success rate was defined as the ratio of the number of young hares that survived to the hunting period per 1 adult female:

$$
W s r=\frac{N j u v}{N a d f}
$$

\section{Results}

In the last five hunting seasons, hiring the hares in the areas constituting the research area showed a clear upward trend (Fig. 3). In this period, on average, over 300 hares were acquired in the circumferences constituting the research area on an annual basis (data from hunts conducted in this area by the hunting club). The acquisition rate from 100 ha of field area increased by over $100 \%$, and on average in the hunting season more than 3 hares were obtained from every 100 ha of field area. This result in recent years is certainly the highest in Poland.

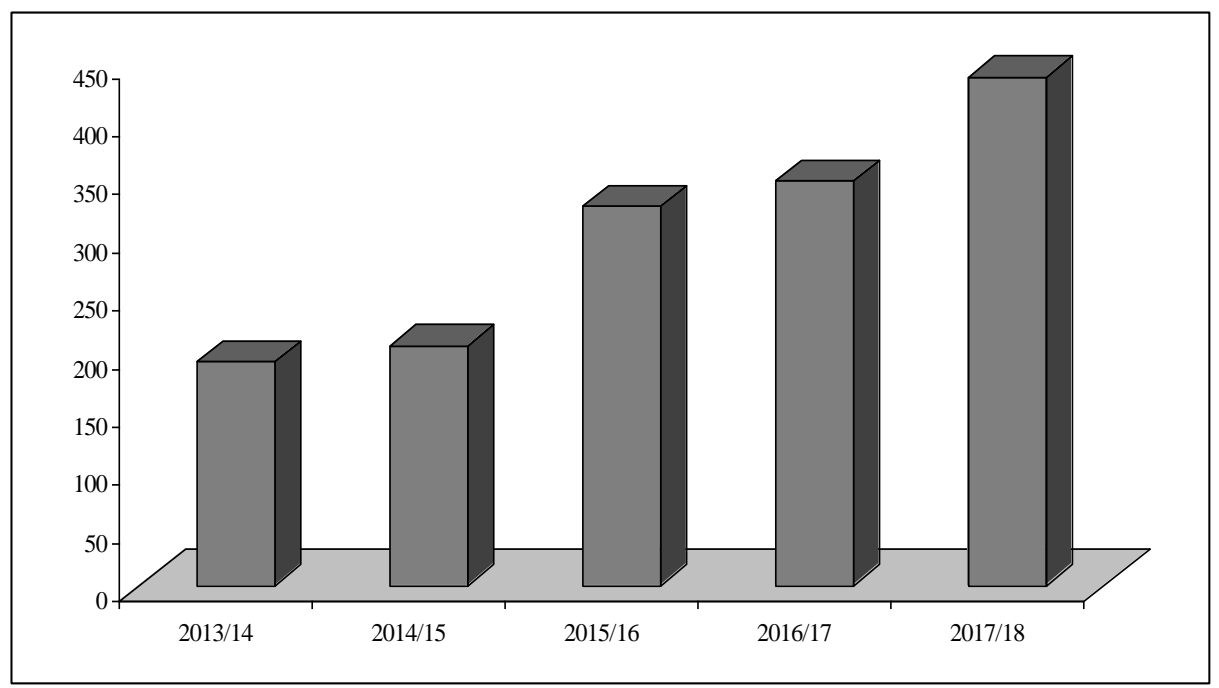

Figure 3. The number and acquisition of a hare with 100 ha of area by shooting in the last 5 hunting seasons in the areas constituting the research area 
The analyzes of hog body mass development carried out show a significant variation of this characteristic between young and adult individuals and the relative stabilization of young and adult hares in the sexual groups (Table 1). The average body weight of 35 young males was $4.18 \mathrm{~kg}$ and young females were lower by $0.14 \mathrm{~kg}$. This difference was not statistically significant $(\mathrm{p}>0.05)$. The average body weights of adult females and males varied only $0.02 \mathrm{~kg}$. On the other hand, predictably, adult hares were much heavier than the young ones. The least stable was the weight value of young females, which is confirmed by the calculated values of standard deviation.

Table 1. Mean and standard deviation of body weight $(\mathrm{kg})$ of acquired hares

\begin{tabular}{c|c|c|c|c|c|c}
\hline \multirow{2}{*}{ Item } & \multicolumn{2}{|c|}{ Male } & \multicolumn{2}{c|}{ Female } & \multicolumn{2}{c}{ Totality } \\
\cline { 2 - 7 } & Young & Adult & Young & Adult & Young & Adult \\
\hline $\mathrm{n}$ & 35 & 16 & 45 & 33 & 80 & 49 \\
$\overline{\mathrm{X}}$ & $4.18_{\mathrm{x}}$ & $4.63_{\mathrm{y}}$ & $4.04_{\mathrm{x}}$ & $4.65_{\mathrm{y}}$ & 4.10 & 4.65 \\
$\mathrm{SD}$ & 0.22 & 0.23 & 0.43 & 0.23 & 0.36 & 0.23 \\
\hline
\end{tabular}

The structure of the sex of hares obtained showed significant variation in the age groups (Fig. 4). Both females prevailed in both young and adult animals. In young hares, the sex structure index was 1:1.29 and in adults it was 1:2.06. The age structure of shot hares was differentiated by gender (Fig. 5), however, in both sexual groups, young animals predominated. In males, the age structure index was 1:0.46 in favor of young animals. In females, the prevalence of juveniles was slightly lower, and the age structure index was at the level of 1:0.73, also in favor of individuals up to one year old. The calculated population reproduction $(E q .1)$ rate was 1.63 , and the reproductive success $(E q .2)$ rate was 2.42 .

\section{Discussion}

Hunting hares in the last hunting seasons in the area covered by the research should be assessed as very high. The average index obtained from 100 ha of area, at the level of about 3 individuals, is not much lower than the size of this species given by Flis (2015), in the area of Wyżyna Lubelska in the hunting season 2004/05-2013/14. It is also close to the lowest indicators of this parameter in the 10-year monitoring period in the experimental circuit located also in the Lublin Upland (Flis, 2016), which data reflect the average national level from the beginning of the twenty-first century (Dziedzic et al., 2002). Densities in central and western Poland given by Kamieniarz and others (2013) in 2006, depending on the season, were within the range of 4.1-9.5 individuals, while the results of the same studies in Germany showed density at the level of 18.8-48.4 individuals/100 ha. Research conducted in Turkey also indicates the diversified density of this species, depending on the type of environment and the season, at the level within the range of 1.67.6/100 ha (Demirbas, 2015). The compaction index in Hungary in the 2014/15 season was in the range of 13-17 individuals/100 ha (Farkas et al., 2016). Nevertheless, in some European countries there are areas in which the population density is much higher and often exceeds 20 individuals per 100 ha area (Pikula et al., 2004; Pintur et al., 2006). The obtained results indicate, that in the area of research, the population density of this species is undoubtedly one of the highest in Poland, which is confirmed by the distributions of collective hunting and calculated index of acquisition from 100 ha. 


$$
-13707 \text { - }
$$

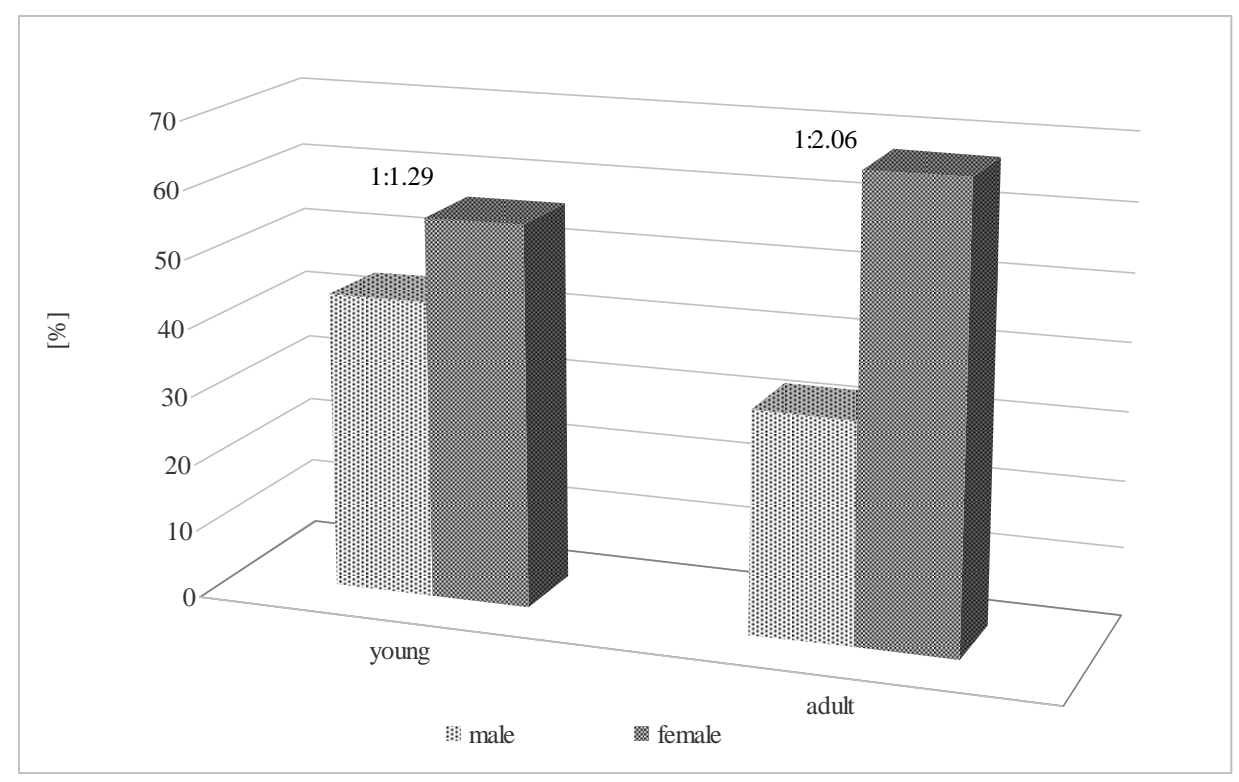

Figure 4. Gender structure of acquired hares

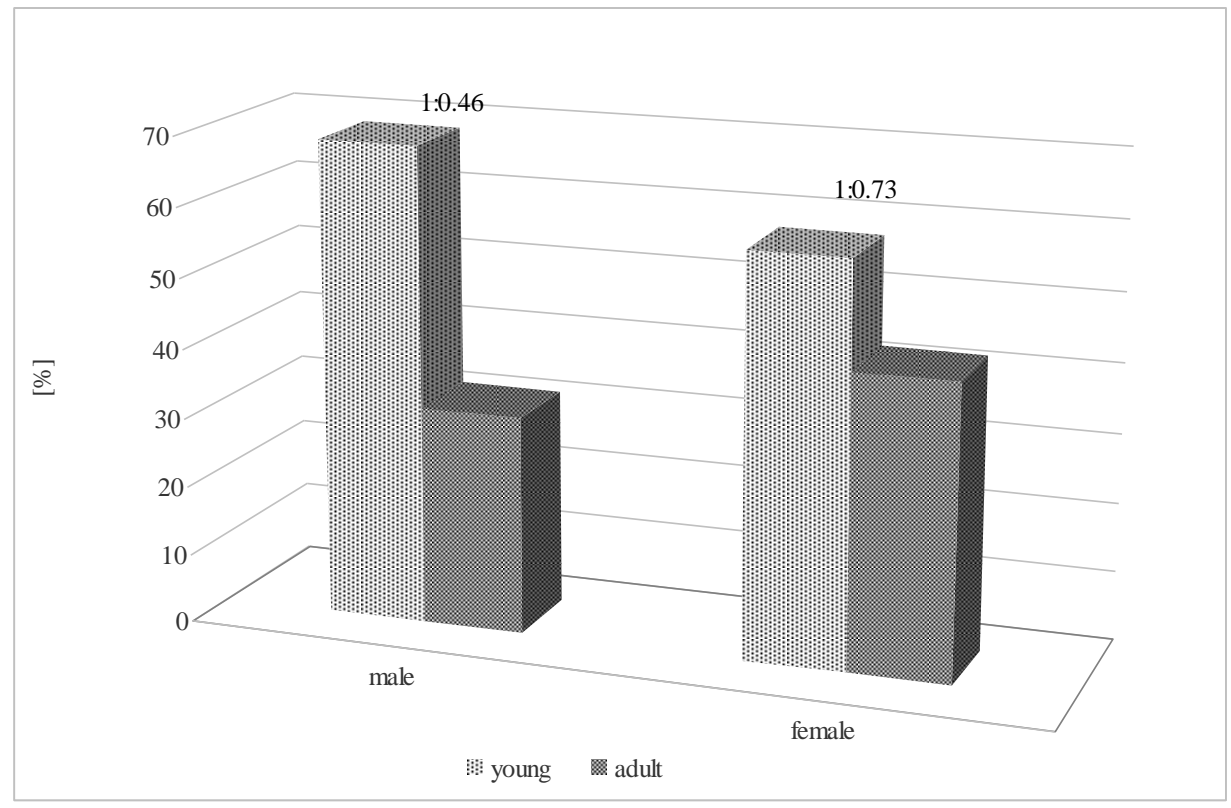

Figure 5. Age structure of acquired hares

The presented body weight results of both male and female hares are higher than those of Flis (2015) conducted in the hunting grounds of the Lublin Upland in the 2014/15 season. Currently, body mass is also slightly higher compared to the average values of this feature in the area of the Lublin Upland and Podlasie obtained in studies conducted in the mid-90s of the last century (Dziedzic et al., 1998). In turn, in Misiorowska and other studies (2014) conducted in areas of the highest population size of this species in our country, average hare body weight varied $(3.42-4.32 \mathrm{~kg}$ ), and a statistically significant difference between the averages was recorded only in age 
groups. Also in the region of Central Pomerania in the years 1998-2001, significant differences between the hare body mass were found only in age groups, and the average value of this feature was $4.13 \mathrm{~kg}$ (Mysłek et al., 2004). The obtained data is also higher than in Croatia in the hunting season 2004/2005, given by Pintura and others (2006), as well as in Hungary in both age and gender groups (Farkas et al., 2016). Therefore, high density indicators in the area of research do not adversely affect the body weight of animals, because it is higher compared to the results presented by other authors from recent years, both from Poland and other European countries.

The obtained sex structure and age structure indicators showing a clear advantage of females and young individuals, regardless of gender, in the study population, are very optimistic, as they indicate that in the research area, the population exhibits developing features, which should directly affect its further development. The values of the reproduction rate and reproductive success indicate a high reproductive potential of the analyzed population, and thus suggest that there should be further dynamic growth. In the presented results, the reproduction rate was definitely higher than that from Misiorowska and other results (2014) carried out in the areas with the highest number of hares in Poland in the hunting season 2009/10, which ranged from 0.36 to 1.26. In turn, the reproductive success rate is only slightly lower than the upper value described by the same authors who fell within the range of 0.7-2.7. Pintur et al. (2006), conducting research in the diverse environments of Croatia in the 2004/05 hunting season, showed that the reproduction rate was environment-dependent and ranged from 0.61 to 1.50 . In the same studies, the reproductive success rate was set at 1.33 to 3.40 . In turn, in research conducted near Nitra in Slovakia, the value of the reproduction rate depending on the season was within the range of 0.76-0.92, and the reproductive success rate from 1.61 to 2.10 (Méres et al., 2016). Thus, the described indicators are within the upper range of this species obtained in some European countries.

\section{Conclusions}

1. The amount of hares obtained in recent hunting seasons on an average level of about 3 individuals from 100 hectares, confirms the high population density index, which can certainly be described as the highest in Poland and one of the highest in Europe.

2. The body weight of the hares obtained, both young (4.10 kg) and adults $(4.65 \mathrm{~kg})$ indicates that the individual condition of the animals is high, and the values of this feature definitely outweigh those from other regions of the country, as well as in some European countries.

3. The structure of sex with a clear predominance of females and the structure of the age where young specimens dominated, indicates a high reproductive potential of the population in the research area, and thus also shows the features of the developing population. This is also confirmed by the high values of the reproduction rate - 1.63 and the reproductive success rate, which value was 2.42 .

4. Analysis of the basic parameters characterizing the population of the hares in the area covered by the study indicates that despite the decline in numbers in many countries, there are areas characterized by the existence of populations with high individual quality and reproductive potential. Thus, it allows to deduce about the potential possibilities of rebuilding the number of hares. 


\section{REFERENCES}

[1] Burel, F., Baudry, J. (1990): Structural dynamic of hedgerow network landscape in Brittany, France. - Landscape Ecology 4(4): 197-210.

[2] Chroust, K., Vodnansky, M., Pikula, J. (2012): Parasite load of European brown hares in Austria and Czech Republic. - Veterinarni Medicina 57(10): 551-558.

[3] Dubinský, P., Vasilková, Z., Hurníková, Z., Miterpáková, M., Slamečka, J., Jurčík, R. (2010): Parasitic infections of the European brown hare (Lepus europaeus Pallas, 1778) in south-western Slovakia. - Helmintologia 47(4): 219-225.

[4] Decors, A., Lesage, C., Jourdain, E., Giraud, P., Houbron, P., Vanhem, P., Madani, N. (2011): Outbreak of tularemia in brown hares (Lepus europaeus) in France, January to March 2011. - Euro Surveillance 16(28): pii: 19913.

[5] Demirbas, Y. (2015): Density of European hare and red fox in different habitats of Kirikkale Province (Central Anatolia), with a low level in hare number and an expected correlation in spring. - Acta Zoologica Bulgarica 67(4): 515-520.

[6] Dziedzic, R., Flis, M., Olszak, K., Wójcik, M., Beeger, S. (1998): Masa ciała zajęcy na Wyżynie Lubelskiej i Podlasiu. - Annales UMCS XVI (35, EE): 261-267.

[7] Dziedzic, R., Dzięciołowski, R., Bresiński, W., Wasilewski, M., Flis, M., Wójcik, M., Beeger, S., Olszak, K., Czyżowski, P., Przypaśniak, J., Wawrzyniak, P. (2000): Wpływ czynników środowiskowych na dynamikę i pozyskanie zajęcy w latach 1989-1999. Materiały konferencji „Zwierzyna drobna jako elementy bioróżnorodności środowiska przyrodniczego", Włocławek.

[8] Dziedzic, R., Kamieniarz, R., Majer-Dziedzic, B., Wójcik, M., Beeger, S., Flis, M., Olszak, K., Żontała, M. (2002): Przyczyny spadku populacji zająca szaraka w Polsce. Wyd. Ministerstwo Środowiska. Fundacja Ekonomistów Środowiska i Zasobów Naturalnych.

[9] Farkas, P., Kusza, S., Majzinger, I. (2016): Analysis of some population parameters of the brown hare (Lepus europaeus Pallas, 1758) in two hunting areas on the Hungarian great plain. - Lucrări Ştiinţifice 18(1): 71-74.

[10] Flis, M. (2009): Zmienność zagęszczeń i preferencji siedliskowych zajęcy w warunkach obwodu łowieckiego w latach 1998-2008. - Roczniki Naukowe Polskiego Towarzystwa Zootechnicznego 5(1): 139-147.

[11] Flis, M. (2013): Synanthropic predators as an environmental threat. - Annales UMSC Sectio EE XXXI: 1: 1-9.

[12] Flis, M. (2015): Zróżnicowanie wieku, płci oraz masy ciała zajęcy w warunkach niskiego zagęszczenia na Wyżynie Lubelskiej. - Sylwan 159(7): 579-585.

[13] Flis, M. (2016): Zróżnicowanie zagęszczenia oraz preferencji siedliskowych zajęcy w warunkach obwodu łowieckiego położonego na Wyżynie Lubelskiej. - Sylwan 16(10): 829-836.

[14] Flis, M., Nozdryn-Płotnicki Z, Wrona, Z., Piórkowski, J. (2016): Zapalenie ziarniniakowe układu rozrodczego u zająca szaraka (Lepus europaeus Pall. 1778) - opis przypadku. Życie Weterynaryjne 91(8): 579-581.

[15] Flis, M., Grela, E. R., Gugała, D. (2017): Occurrence of rabies in Poland in 2011-2015 in relation to the free-living fox population. - Medycyna Weterynaryjna 73(1): 43-47.

[16] Flis, M., Grela, E. R., Gugała, D. (2018): Efektywność doustnej immunizacji lisów wolno żyjących w ograniczaniu wścieklizny w latach 2011-2015. - Medycyna Weterynaryjna 74(3): 203-208.

[17] Frylestam, B. (1980): Reproduction in the European hare in southern Sweden. Ecography 3(1): 74-80.

[18] Gołdyn, B., Hromada, M., Surmacki, A., Tryjanowski, P. (2003): Habitat use and diet of the red fox Vulpes vulpes in an agricultural landscape in Poland. - Zeitschrift für Jagdwissenschaft 49: 191-200. 
[19] Goszczyński, J., Wasilewski, M. (1992): Predation of foxes on a hare population in central Poland. - Acta Theriologica 37(4): 329-338.

[20] Hackländer, K., Zeitlhofer, C., Ceulemans, T., Suchentrunk, F. (2011): Continentality affects body condition and size but not yearly reproductive output in female European hares (Lepus europaeus). - Mammalians Biology - Zeitschrift für Säugetierkunde 76: 662-664.

[21] Hušek, J., Panek, M., Tryjanowski, P. (2015): Predation risk drives habitat-specific sex ratio in a monomorphic species, the brown hare (Lepus europaeus). - Ethology 121(6): 593-600.

[22] Jezierski, W. (2004): Zając - ginący gatunek. - Łowiec Polski 6: 12-15.

[23] Kamieniarz, P., Voigt, U., Panek, M., Strauss, E., Niewęłowski, H. (2013): The effect of landscape structure on the distribution of brown hare Lepus europaeus in farmlands of Germany and Poland. - Acta Therriologica 58(1): 39-46.

[24] Kondracki, J. (2000): Geografia Regionalna Polski. - PWN, Warszawa.

[25] Kryński, A., Chudzińska-Popek, M., Majdecka, T. (2007): Środowisko współczesnych agrocenoz a sytuacja zająca szaraka. - Nauka łowiectwu. Cz. 2. Zającowi na ratunek. Wyd. Samorząd Województwa Mazowieckiego, Warszawa, pp. 110-113.

[26] Kornaś, S., Wierzbowska, I., Wajdzik, M., Kowal, J., Basiaga, M., Nosal, P. (2014): Endoparasites of European brown hare (Lepus europaeus) from Southern Poland based on necropsy. - Annals of Animal Science 14(2): 297-306.

[27] Lewandowski, K., Nowakowski, J. (1993): Spatial distribution of brown hare Lepus europaeus in habitats of various types of agriculture. - Acta Theriologica 38(4): 435-442.

[28] Méres, J., Ostrihoň, M., Slamečka, M., Kaštier, J. (2016): Population structure of brown hare (Lepus europaeus): a case study in selected areas of Nitra region [2013]. - Acta Facultatis Forestalis Zvolen 55(suppl. 1).

[29] Misiorowska, M., Ludwisiak, Ł., Nasiadka, P. (2014): Wybrane parametry populacyjne zająca szaraka (Lepus europaeus L.) w rejonach największej liczebności gatunku w Polsce. - Sylwan 158(12): 901-910.

[30] Mysłek, P., Kalasińska, E., Bartyzel, B. (2004): Size of the brown hare (Lepus europaeus Pallas 1778) living in Central Pomerania in Poland. - Zoologia Poloniae 49(1-4): 237244.

[31] Nasiadka, P., Dziedzic, R. (2014): Podręcznik najlepszych praktyk ochrony kuropatwy i zająca. Dla różnorodności biologicznej. - Centrum Koordynacji Projektów Środowiskowych, Warszawa, pp. 66-118.

[32] Panek, M. (2007): Drapieżnictwo lisów na zającach. - Nauka łowiectwu. Cz. 2. Zającowi na ratunek. Wyd. Samorząd Województwa Mazowieckiego, Warszawa, pp. 96-105.

[33] Panek, M. (2018): Habitat factors associated with the decline in brown hare abundance in Poland in the beginning of the 21st century. - Ecological Indicators 85: 915-920.

[34] Panek, M., Kamieniarz, R. (1999): Relationships between density of brown hare Lepus europaeus and landscape structure in Poland in the years 1981-1995. - Acta Theriologica 44: 67-75.

[35] Panek, M., Kamieniarz, R., Bresiński, W. (2006): The effect of experimental removal of red foxes Vulpes vulpes on spring density of brown hares Lepus europaeus in western Poland. - Acta Theriologica 51: 187-193.

[36] Pielowski, Z. (1976): On the Present State and Perspectives of the European Hare Breeding in Poland. - In: Pucek, Z., Pielowski, Z. (eds.) Ecology and Management of European Hare Populations. PWRiL, Warszawa, pp. 25-27.

[37] Pielowski, Z. (1979): Zając. Monografia przyrodniczo-łowiecka. - PWRiL, Warszawa.

[38] Pikula, J., Beklova, M., Holesovska, Z., Treml, F. (2004): Ecology of european brown hare and distribution of natural foci of tularemia in the Czech Republik. - Acta Veterinaria Brno 73(2): 267-273. 
[39] Pintur, K., Popović, N., Alegro, A., Severin, K., Slavica, A., Kolić, E. (2006): Selected indicators of brown hare (Lepus europaeus Pallas, 1778) population dynamics in northwestern Croatia. - Veterinarski Arhiv 76: 199-209.

[40] Schai-Braun, S. C., Reichlin, T. S., Ruf, T., Klansek, E., Tataruch, F., Arnold, W., Hackländer, K. (2015): The European hare (Lepus europaeus): A picky herbivore searching for plant parts rich in fat. - PloS One 10(7): e0134278.

[41] Schmidt, N. M., Asferg, T., Forchhammer, M. C. (2004): Long-term patterns in European brown hare population dynamics in Denmark: effects of agriculture, predation and climate. - BMC Ecology 4: 1-7.

[42] Schrödl, G. (1991): Ein Stichprobenverfahren zur Biotopcharakterisierung Niederwildgebieten. - Beitrage zur Jagd und Wildforschung XVII: 93-98.

[43] Stroh, G. (1931): Zwei sichere Altersmerkmale beim Hasen. - Berliner Tierärztl. Wschr. 47: $180-181$.

[44] Wasilewski, M. (2007): Drapieżnictwo a zwierzyna drobna. - Nauka łowiectwu. Cz. 1. Kryzys zwierzyny drobnej i sposoby przeciwdziałania. Wyd. Samorząd Województwa Mazowieckiego, Warszawa, pp. 34-38.

[45] Witek, T. (1991): Warunki przyrodnicze produkcji rolnej: woj. lubelskie. - IUNiG, Puławy. 